\title{
The Year is 2000: What is It to Be British?
}

\author{
Junaidi
}

ABSTRACT Identitas adalah isu sentral dalam perjalanan sebuah bangsa, tidak terkecuali bangsa Inggris. Dengan melihat perjalanan konstruksi identitas bangsa Inggris dari abad ke-18, tulisan ini mencoba memahami proses budaya yang membentuk identitas. Berbagai faktor internal dan eksternal mempengaruhi proses ini dan meyakinkan bahwa identitas bangsa Inggris sedang diperdebatkan. Berbagai makna seputar identitas Inggris juga dibahas untuk menunjukkan adanya negosiasi dalam proses pembentukan identitas. Pada akhir pembahasan dilihat bahwa identitas lebih bersifat majemuk, namun masa depan Inggris sebagai sebuah komunitas imajiner, ketika semua elemen masyarakat merasa dihargai, memiliki kesempatan yang sama dalam mengaktualisasi diri dan menikmati persahabatan dalam semangat keberagaman, masih perlu dilihat kemudian.

KATA KunCI Konstruksi identitas, perubahan, Britishness, keberagaman

Britain is at a turning point, a crossroads

(The Parekh Report, p. 2)

On October $11^{\text {th }}$, 2000 The Commission on The Future of Multi-Ethnic Britain, an independent think-tank established by the Runnymede Trust, published its report on the current state of Britain. ${ }^{1}$ Their mission was to examine the current state of race relations in contemporary Britain through a series of interviews, seminars and discussions. As a result, their recommendations covered different areas, from legislation to a new way to see British cultural identity.

This report is culturally significant because it challenges the notion of Britishness and proposes some ways to invent an agreed future for Britain. By doing so, it contributes ideas about race-relation and ethnicity to the national debate and implies an emergence of a stronger negotiating force in race and ethnicity issues. It also shows that a redefinition of a place called Britain for their inhabitants is inevitable. Carter, Donald and Squires (1993: vii) seem to agree with this. For them, the presumed certainties of cultural

\footnotetext{
${ }^{1}$ For Commission membership see The Runnymede Trust (2000), Appendix C, p 366-71. It is also known as The Parekh Report.
} 
identity located in particular places with a shared tradition and perspective have been increasingly disrupted and displaced. In short, the Report refuses the fixed notion of identity.

Furthermore, it seems to imply a struggle between two different perspectives of Britishness as suspected by Iain Chambers (1993) in Narratives of Nationalism. He says:

Here we face the possibility of two perspectives and two versions of Britishness. One is Anglo-centric, frequently conservative, backward looking, and increasingly located in a frozen and largely stereotyped idea of the national culture. The other is ex-centric, openended, and multi-ethnic. The first is based on a homogeneous 'unity' in which history, tradition, and individual biographies and roles, including the ethnic and sexual ones, are fundamentally fixed and embalmed in the national epic, in the mere fact of being 'British'. The other perspective suggests an overlapping network of histories and traditions, a heterogeneous complexity in which positions and identities, including that of the 'national', cannot be taken for granted, are not interminably fixed but are in flux.

This struggle can be seen from its representations in the media. Since the publication of the Report there has been a number of responses. Some are welcoming, some are furious. The Daily Telegraph quoted Mike O'Brien who was welcoming the report. He said that it was timely and added much to the current debate on multi-ethnic Britain. On the other hand, William Hague attacked the Report. For him, it exemplifies the new "anti-British disease" (The Daily Telegraph, 13 October 2000).

Another important Report is the two-year study in 28 foreign countries by The British Council. The result shows that 'Cool Britannia' has not worked satisfactorily. The Independent quoted the Report which showed that most educated young people aged twenty-four to thirty-five overseas still see the British as stuffy traditionalists who are racially intolerant and refuse to embrace the modern world. Although most respondents recognised that Britain was a multi-cultural society, few felt that they were happy as one. The Report certainly affected the way Britain projects its image overseas (Burrell 2000).

In his controversial Britain TM Leonard (1997) argues that to understand the British image abroad, one must see how it is mirrored in what the British themselves think of their identity. He shows that Britishness is losing its importance as the most important components of identity. Only 50 per cent of people see Britishness as the most important components of their identity, compared to 66 per cent who choose principles and values as the most important. He suspects that the present image abroad is caused by the confusion of this changing British identity and less coordination among the government bodies responsible for projecting the image abroad (Leonard, 1997: 23).

Given these findings, it is clear that a discussion on national identity is still a major issue in Britain now. It is therefore important to examine the underlying cultural process that is shaping British identity.

In this essay I attempt to discuss the current debate on what it is to be British in the year 2000. I shall try to discuss some theoretical approaches to 
identity construction. Having said that, different negotiated meanings and perceptions about being British from historical perspective will be examined. Finally, the discussion on the current state of Britishness will conclude this essay. I shall organize my essay under three headings: (1) Theoretical Approaches to Identity Construction; (2) Constructing Britishness: A Historical Perspective; and (3) British Identity: The Current State of Britishness.

\section{Theoretical Approaches to Identity Construction}

As a point of departure, we first need to define what is meant by identity. One distinction would be between the essentialist and non-essentialist perspectives. In Studying Culture Giles and Middleton (1999) understand that from an essentialist perspective "identity is fixed in an originating moment, that there is a 'true', authentic, unchanging set of characteristics that belong to, say Asians or Europeans." On the contrary, "a non-essentialist perspective questions whether it is possible to speak of a 'true' identity that is fixed for all time and in all places." To illustrate this they question the determining factors defining a third-generation Japanese woman, living in America, who is unable to speak Japanese, as Japanese. They continue (1999: 36):

Is it biological genes, citizenship in the sense, for example, of holding an American or Japanese passport as a naturalized citizen, language, place of birth, place of current residence or a personal and subjective sense of herself as 'Japanese' or 'American'?

The same question can then be applied to the third generation of 'ethnic minorities' in Britain. For example, how would a Chinese descendant who was born from a Scottish mother and Chinese father, living in London, speaking English and Chinese, recognizing Christianity as his religion, identify himself? What if he marries a third-generation Indian woman in Coventry? What is the identity of the child?

The answer to this may be what he, his wife and their child identify themselves with. They may call themselves British, British Asian, Londoners, or even Scottish although the others do not concur. Here an identity position is being interpellated (Althuser in Woodward [ed.] 2000: 19). He recognizes himself in a particular identity and think 'that's me'. Turner and his colleagues called this 'self-categorization theory'. However, his choice is not free of the structure of the society and the place in which he is living. There are, for example, categories based on economic factors (class), gender, ethnicity, race and power imposed to him as a citizen. Moreover, people see him in relation to somebody else. Some think he is one of 'us' while the others say he is one of 'them'.

Woodward defines 'us' to include people who are the same as us, using the criteria which we think mark us out as the same, for example being white; 'them' are marked out as different because 'they' are not the same as 'us'. A majority of people often use the distinction of 'us' and 'them' to 
justify superiority. In the case of race, the attempt to exclude people on grounds of race may be described as racist. This is what is to be known as difference, which often involves unequal oppositions (Woodward [ed.] 2000: 33).

So if that is the case, can people actively assert their identities against the majority? If so, how can they do it? One strategy, for example, is through collective actions to fight for a recognition of identity in legislation. The social constraints of inequality will need to be negotiated.

Manuel Castels in The Povver of Identity (1997) sees the construction of identity as social and always takes place in a context marked by power relationship. He proposes that there are three forms of identity building:

1. Legitimizing identity: introduced by the dominant institutions of society to extend and rationalize their domination vis a vis social actors; fits the theory of authority, domination and nationalism; creates a civil society.

2. Resistance identity: generated by those actors who are in positions and conditions devalued and/or stigmatized by the logic of domination, thus building trenches of resistance and survival on the basis of principles of different from, or opposed to, those permeating the institutions of society; leads to the formation of communes or communities such as ethnically based nationalism, religious fundamentalism, and territorial communities which often 'arise out of a sense of alienation and resentment against unfair exclusion, whether political, economic or social'; usually defensive in terms of dominant ideologies.

3. Project identity: when social actors, on the basis of whatever cultural materials are available to them, build a new identity that redefines their position in society and, by so doing, seek the transformation of the overall social structure, for instance, Feminism which challenges Patriarchalism.

Moreover, he argues that the construction of identities uses building materials from history, geography, biology, productive and reproductive institutions, collective memory and personal fantasies, power apparatuses and religious revelations. Then, individuals, social groups, and societies process these and rearrange their meaning according to social determinations and cultural projects rooted in their social structure and in their space/time framework (Castells 1997: 6-12).

In contemporary British society the tensions between the essentialists and non-essentialists have created opportunities and uncertainties in one's identity. The 'classic' example for opportunities may be the social mobility experienced by Diana Spencer and Sarah Ferguson. However, with the European Union, some people experience uncertainties. They are worried about what is going to happen to their country's sovereignty. What sort of identity are they going to have as Europeans? Most of all, as the Report on the Future of Multi-Ethnic Britain shows, people begin to question what it is to be British now and in the future. The idea that being British which means to be white, a member of Church of England and middle-class English is 
now being challenged. Clearly such uncertainties and opportunities are parts of the cultural process in the changing British identity. Taking that into account, I shall now discuss the construction of British identity.

\section{Constructing Britishness: A Historical Perspective}

Historically Britishness has experienced a long on-going evolution process. Since 2000 BC the British Isles have been inhabited by different migrant groups and invaders. These people have brought their cultures and shaped the political and cultural life of the land. According to Illustrated Guide to British History (2000) this process started with the Beaker people in 2000 BC; the Celts in 900 BC; the Romans in 55 BC; the Angles, Saxons and Jutes in 426 AD followed by the Vikings in 793 AD. The Normans came in 1066; the substantial Jews community arrived in 1070 and 1655; the French Protestant Huguenots in 1572; and Africans, many as house slaves in eighteenth century; Russian Jews came in 1881; German refugees in 1940; West Indian immigrants in 1952; Indians from Uganda and Kenya in 1969; Vietnamese refugees in 1975, together with other immigrants from various Commonwealth countries (Evans [ed.] 2000: 19). During this time identity construction has been changing in relation to the political, personal and cultural identification.

So, who are the British? Historians have shown that the origin of Britishness was in about 1536 when Wales became the principality of England and took a stronger root in 1603. One should note that Wales was integrated through an Act of Incorporation rather than an Act of Union (Leonard 1997). At that time King James VI of Scotland became James I of England and Ireland. However, the British state did not exist until later. Although the two kingdoms (Scotland and England) were under one monarch, they had their own systems and could not tax each other. Only after the Act of Union in 1707 under Queen Anne did the two kingdoms merge into Great Britain.

At the beginning the union of Scotland and England was more like an international agreement than a constitution. Clauses stated the economic regulation as well as the political arrangement between the two kingdoms. In the economy, for example, it is stated that all the subjects of the United Kingdom of Great Britain shall have full freedom of trade within the said United Kingdom. Nevertheless, Scotland is exempted from certain duties enforced in England like on malt, windows, lights, stamped paper, coals, and cinders consumed in England.

In politics, the two kingdoms are united by the name of Great Britain. The succession to the monarchy shall be to Princess Sophia of Hanover and her Protestant heirs. Although the laws concerning regulation of trade, Customs and Excises and the seal are the same, Scotland still retains its Court of Session, heritable offices, the Church of Scotland and the rights and privileges of the royal burghs. Most importantly, Scotland sends peers 
to the House of Lords and the House of Commons of the Parliament in Westminster with the same rights to vote (Davies 2000: 969-70).

To invent, bind and nourish the new identity as British, some factors must be involved. Colley in her book Britons: Forging the Nation 1707-1837 (1996) argues that Great Britain was invented in the eighteenth century for several reasons. She says:

It was an invention forged above all by war, time and Time again, war with France brought Britons, whether they hailed from Wales or Scotland or England, into confrontation with an obviously hostile Other and encouraged them to define themselves collectively against it. They defined themselves as Protestants struggling for survival against the world's foremost Catholic power. They defined themselves against the French as they imagined them to be, superstitious, militarist, decadent and unfree. And, increasingly as the wars went on, they defined themselves in contrast to the colonial peoples they conquered, peoples who were manifestly alien in terms of culture, religion, and colour (Colley 1996: 5).

The three factors (Protestantism, war and empire) forged the nations and invented a new identity for the people, that is to be British. On the one hand, the threats from Catholicism and Continental power represented by the French created uncertainties and a need to stand together against such threats. For them, a French victory would damage their security, livelihood, and religious identity. This identity was even stronger when the people had the feeling that their islands were separated from the Continent, their free trade established before other European countries, and the fact that England and Scotland were the most urbanised parts of Europe at that time (Colley 1996: 389). On the other hand, the Empire and foreign trade had brought vast opportunities for wealth and a political awareness to the society. As Colley strongly argues, men and women became British patriots and took a more active role in citizenship in order to show their prominence in society, to gain commercial benefit from the Empire, to satisfy a desire for excitement, or to get admission to full citizenship, a means to get a vote and a say in the state affairs (Colley 1996: 391).

In this context it is worth noticing that Britishness does not mean the integration of Englishness, Scotishness or Welshness. Instead, it was superimposed over internal differences in response to conflict with the Other. Nevertheless, the constituents of Britishness remain there until now. As Britishness developed, they had to redefine themselves under new circumstances. Hobsbawm and Ranger (1992) have discussed this in their Invention of Tradition. Highland dress, for instance, was invented after 1707.

In addition, at the peak of Empire in the Victorian era, Britishness represented Great Britain's destiny as the Protestant Israel in which God had entrusted an Empire to spread the Gospel. ${ }^{2}$ This later nourishes Britons' sense of superiority against alien peoples. One should also note that Britishness was primarily dominated by Englishness and became a national

\footnotetext{
${ }^{2}$ Brian Stanley, The Bible and the Flag: Protestant Missions and British Imperialism in the nineteenth and Twentieth Centuries (1990) as cited in Colley, p. 388.
} 
identity with the advent of industrialization and mass literacy in the nineteenth century. ${ }^{3}$ The result remains until now. As one may notice UK is sometimes thought of as England for some people, particularly the English.

The fourth factor that binds the people together and gives the symbols of Anderson's idea of 'imagined community', is the Monarchy and the cultural symbols sponsored and devised around it. During the Protestant Hanoverian dynasty the extensive inventions of Britishness provided symbols and rituals for the nation. The process continues until now through images, stories, flags, the anthem, uniforms, traditions and other components of culture, which are later on institutionalised (Guibernau and Goldbladtt in Woodward [ed.] 2000: 132-4). The composition of the British national anthem in 1740, the first design and use of modern form of Union Jack in 1801, the inauguration of National Portrait Gallery in 1856, the reinvention of Queen Victoria as Empress of India in 1877, the founding of National Trust in 1895, the first BA in English Literature at Oxford University in 1896, the founding of BBC in 1922, and the first instituted Royal Christmas in 1932 are wellknown examples (Leonard 197: 25-6).

Since 1707 the new institutions and icons of Britishness have been a source of identification for the British citizens alongside their Englishness, Scotishness, Welshness or Irishness. The success of Empire and industry gave them confidence, pride, and a sense of superiority.

\section{British Identity: The current State of Britishness}

Uncertainties, Opportunities and Diversities At the heart of the notion of Britishness one finds it hard to deny the complexities and heterogenous structure of the construction for it involves many things like nationalism, class, gender, ethnicity, religion, race, locality or generation. In fact, there has never been a single 'British way of life'. Furthermore, the subjectivity in interpreting the notion, the power relations among the elements, the historical context and places intersect one another to complicate the matter. Bearing this in mind, an attempt to examine the complete current state of Britishness seems to over ambitious. Therefore, I shall try to discuss the major issues in the changing meanings of Britishness as experienced by the people and seen by the 'Others' abroad as well as how they are represented in different images and stereotypes.

So what is it to be British now? People are now experiencing changes in their life. Consequently, uncertainties about their identity arise. Leonard (1997) demonstrates that the current meanings of Britishness differ from the nineteenth century's. Between 1983 and 1996 there has been a decline of confidence in institutions like the Houses of Parliament, the Monarchy, the Church, the legal system, the Armed Forces, the Police, the Civil Service, the press, and the Union Jack. For example, the percentage of people who

${ }^{3}$ Monserrat Guibernau and David Goldblatt, "Identity and Nation," in Woodward (ed.) 2000: 132 . 
had 'great confidence' or 'quite a lot of confidence' in Parliament dropped from 54 per cent in 1983 to 10 per cent in 1996; only 13 per cent of British people 'respect' the monarchy and 45 per cent do not think that Britain will have a monarchy in 50 years' time; in the church from 52 per cent to 25 per cent and in the legal systems confidence fell from 58 per cent to 26 per cent.

The globalization of business ventures and the rise of satellite and cable television influence national institutions. The fact that $\mathrm{BBC}$ can never again represent the voice of the nation, defining its culture and even its accent; have made it less of a national institution. In addition, British Telecom has become BT, and British Airways is redefining itself as a carrier of a global rather than a national one. Even the Union Jack has different significationat times a racist icon for skinheads and fascists (Leonard 1997: 27-8).

From the age point of view, Britishness is interpreted differently. The British Social Attitudes survey (the $13^{\text {th }}$ report) found that 61 per cent of people over 60 saw Britain as the best in the world and views other ethnicities as a threat. One in three over $65 \mathrm{~s}$ agreed that to be fully British is to share British customs and traditions; 63 per cent of over 65 s thought to be Christian, and 60 per cent of over $55 \mathrm{~s}$ believed that one needs to have been born in Britain. In contrast, only one in twenty 18 to 24 -year olds believed that it is impossible for people who do not share British customs and tradition to be fully British; only 11.5 per cent of 18-34 years olds thought that it was important to be Christian. 37 per cent agree that to be British is to have been born in Britain (Leonard 1997: $32-3$ ). ${ }^{4}$

The meaning of Britishness is certainly different for each ethnicity. The English will speak of Britain and mean England. Bassnett (2000) explains that most of the unconscious, collective idea of England relates to an image of England as a unified entity, the island fortress, the beauty of rural England and images of a colonial past. Moreover, England also deals with the divisive class system, the dominance of London, sharp divisions in English life, between rich and poor, North and South, or even the poorer agricultural East and the richer, more urban West. For Gwynfor Evans, former leader of Plaid Cymru, Britishness is another word for Englishness; it is a political word which arose from the existence of the British state and which extends Englishness over the lives of the Welsh, the Scots and the Irish (Bassnett 1999). The ethnic minorities may interpret Britishness as a reminder of the colonial past (The Runnymede Trust 2000: 38).

Leonard is clearly more interested in examining the formation of British economic positions in marketing the nation in a global economy. He emphasizes the need to renew British identity and projects it in a more strategic way to the world. Although his research was to examine Britain in 1997 and things may have changed since then, it gives a valuable description

+ To be Christian here may be best understood as to be a member of Church of England as it used to give more access to public office and positions in society. Of course, it has changed ever since, particularly after Equal Opportunities Act has been introduced. 
of Britishness. However, he has not discussed the identity construction of the migrants and their descendants thoroughly.

As a result of post-war migration and globalisation, the next question worth asking is how do the so-called 'ethnic minority' experience their life in Britain? Is it a home for them? How do they identify themselves? How do the 'majority' locate them in the structure of Britishness? What about the majority? What happens to the Englishness, Scottishness, and Welshness or Irishness?

The Report on the Future of Multi-Ethnic Britain (2000) portrays the other disturbing results of being British. Firstly, it defines the notion of Britishness, secondly, it examines the obstacles to redefine British identity and finally it puts forward a vision and the strategies of change. Their findings represent a non- essentialist perspective of identity construction.

To talk about Britishness is asking about Britain as an imagined community, which needs to reimagine itself for the future. As the Report puts it:

Will it try to turn the clock back, digging in, defending values and ancient hierarchies, relying on a narrow English-dominated, backward-looking definition of the nation? Or will it seize the opportunity to create amore flexible, inclusive, cosmopolitan image of itself? Britain is at a turning point. But it has not yet turned the corner. It is time to make the move (The Runnymede Trust 2000: 14).

The questions above represent the questions of Britishness, the future of it and the need to see the story in different perspectives. The answer to the first question lies on how the story is imagined. There have been many versions of it depending on different purposes. First is a belief that Britain has been unified since time immemorial. The respect and continuity of tradition, social conventions and ancient institutions with roots in an ancestral past have given the nation stability and its people a striking cultural unity. Second is the notion that Britishness has been evenly diffused across the kingdom. Third, English experience has been readily understood as representing the whole United Kingdom. The fourth is that the British are an island race, and their mentality is shaped by a long and sturdy independence, free from foreign contamination since Norman times. In this sense the British are a special and superior sort of people (The Runnymede Trust 2000: 15).

The four imagined stories have been contested as Britain is experiencing social and cultural changes like globalisation, the decline in Britain's position as a world power, integration with Europe, devolution, the end of empire, the rapid advance of social pluralism and post-war migration. As for the first story, it is clear that historically the present United Kingdom of Great Britain and Northern Ireland was invented in 1922. The second is refutable as there have always been many ways of being British. People identify themselves in relation to Britishness, religion, class, gender, generation, ethnicities, local and regional loyalties. For example, one can identify oneself with British, English/Scottish/Welsh, Yorkshire, Cardiff, London or one's 
own county. The third story has long been challenged by the Scots, the Welsh and the Irish, calling themselves nations (The Runnymede Trust 2000: $22-6)$. Finally, the reality for the fourth story is now different due to the decline of Britain's position as a world power, and its economic competitiveness in global market.

As things have been changing in post-imperial Britain, the imagined stories create uncertainties and the rise of ethnic nationalism as well as civic nationalism. Guibernau and Goldblatt (2000) define ethnic nationalism as a nationalist project in which citizenship and membership of the nation is determined by ethnic origin alone, irrespective of political and cultural allegiances and length of residence in a nation while in civic nationalism it is based on residence and allegiance to the ruling civic and political institutions and not on race, ethnicity or language (Guibermau and Goldblatt in Woodward [ed.] 2000: 145). The former is strengthening with the rise of Scottish, Welsh and Irish nationalism, leaving Englishness to redefine itself. In fact, Ireland's economy is the fastest growing in Europe and is seen as an exciting, innovative 'Celtic tiger' (Leonard 1997: 42). ${ }^{5}$ The later was more dominant in the Imperial era where people from the isles and other countries in the empire stood and fought for the British Empire.

The Report warns that these strong national sentiments are potentially dangerous when elevated into a general theory of the superiority of your own kind, your own people, your own language, just because it is yours. It is particularly dangerous when there is an ambiguity about who exactly the terms 'you' and 'yours' refers to (The Runnymede Trust 2000: 18).

In line with the argument, Ann Leslie (1998) fears the rise of English nationalism. She says:

Things, however, have changed. The English have woken up to the fact that the Scots and the Welsh increasingly call themselves "nations", not regions as we have always called them. Well, if Scotland is a nation, and Wales is a nation, and Ireland is a nation, what is England? The English, having been complacently boss nation for so long- first over all other Britons, and secondly over much of the world-do not know what they are anymore.

\section{She continues:}

Lacking a sense of what being English now consists of, the former boss nation is far more likely to express its sense of loss through hatred of others. That is why I fear the rise of English nationalism. ${ }^{6}$

As for the migrants who came to Britain either as workers, refugees, asylum seekers or for other reasons, things are not as easy as they thought. The green and pleasant land of England, Scotland and Wales is pleasanter for white people, but not for those who are black or Asian. Being labelled as ethnic minorities, they are often seen as the Others (or the aliens) because of

${ }^{5}$ Bill Clinton also mentioned about this during his visit to University of Warwick, 14 December 2000.

${ }^{6}$ For more discussion, see Ann Leslie, English Identity in www.popcultures.com. 
their biologically derived signs (skin colour, hair, features, body type) and cultural features (way of life, customs, language, religion and dress). The representation of this otherness for any sexuality continues in the mainstream press and popular cartoon in the twentieth century. It involves stereotypes about difference and inferiority and the use of power to exclude, discriminate, or subjugate. Some are even institutional (The Runnymede Trust 2000: 62). ${ }^{7}$

The identity for these elements of society varies. Contrary to common stereotypes, their identities are not homogenous. In fact, they are multiple. Young people do not see themselves as either wholly British or wholly Indian or West Indian. For example, in The Buddha of Suburbia, Hanif Kureishi's narrator, Karim sees himself as a 'new breed' - a hybrid produced by his Indian background and his English upbringing (his father is a first-generation Indian in Britain and his mother is white, British, working class). ${ }^{8}$

\section{CONCLUSION}

In this essay I have attempted to show the underlying cultural process that creates the current Britishness. As I have discussed, the meanings and the construction process of Britishness are situated in socio-historical context. In the eighteenth and nineteenth century Britishness superseded other regional identities without eliminating them. It was a new identity forged for political, religious and economic interests. As the cultural process is changing rapidly in the twentieth century, the traditional meanings of Britishness are challenged and need to be redefined. The causes are related to the breaking up of Empire, the decline of Christianity, devolution, globalization, migration, changes of values and technological advancement.

Here, different elements in the society try to negotiate their positions in a new meaning and make their ways of life known to the others. As a result, the country has experienced diversities in religion, ethnicity, tradition, language, tradition, and way of life. In food, for instance, the meals are not only fish and chips, but also pizza, curry, Chinese noodles, kebab, and rice. Multiculturalism has been taken as policy to define British way of life although it is not formally written.

The reforms and changes in gender equality, race relation, and traditional institutions like Parliament represent the cultural process to redefine British identity. It is not as easy as it may sound. In fact, it creates uncertainties. People feel safe when they identify themselves with different regionalism and localities as can be seen in the case of ethno-nationalism, class, gender, religion, or subculture. Problems like injustice, inequality, racism, xenophobia,

${ }^{7}$ Here individuals are seen and judged by simple and fixed group differences. Racism has existed and continues to exist in all societies (p. 63) for economic, religious and political reasons. The target is not only the 'non-whites'. In fact, it could happen among the' whites' or the 'nonwhites' [sic].

" Quoted in Giles and Middleton, p. 46. 
Islamophobia, stereotyping and prejudice towards one another in any forms are among the consequences. Although progress has been satisfactory, the challenges to create a more cohesive and inclusive society remain.

It is clear that identity is more heterogeneous. Yet the consensus about Britishness is still in debate by those with essentialist and non-essentialist perspective. The future of Britain as an imagined community where all citizens and communities feel valued, enjoy equal opportunities to develop their respective talents, lead fulfilling lives, accept their fair share of collective responsibility and help create a communal life in which the spirit of civic friendship, shared identity and common sense of belonging goes hand in hand with love of diversity remain to be seen."

It is interesting to observe the on-going redefinition of people's identity, often seen with the past into a more modern, open, and inclusive identity, the rise of ethno-nationalism, the integration with EU and globalized market and the development of current cultural identities. Will Britain be able to move forward? Britain is indeed at a turning point.

\section{BiBLIOGRAPHY}

Aaronovitch, David (2000), "There's no Such Thing as British History," in The Wednesday Review, The Independent, 11 October.

Bassnett, Susan (1999), "Discovering Englands" in Looking into England Conference Report, www.britishcouncil.org.uk.

Bassnett, Susan (ed.) (1997), Studying British Cultures: An Introduction. London: Routledge. Brah, Avrah (1996), Cartographies of Dinsporil. London and New York: Routledge.

Brown, Yasmin Ali (2000), "Why Does Questioning the Nature of Britishness Raise So Much Fury?" In www.independent.co.uk, 18 October.

Burrell, Ian (2000), "Britain Seen as Land of Tea and Skinheads," The Independent, 10 November. Carter, Erica, James Donald and Judith Squires (eds.) (1993), Space and Place: Theories of Identity and Location. London: Lawrence and Wishart.

Castells, Manuel (1997), The Power of Identity. Oxford: Blackwell.

Cobley, Paul and Litza Jansz (1998), Semiotics for Beginners. Cambridge: Icon Books Ltd.

Colley, Linda (1999), "Blueprint for Britain," The Observer, 12 December.

Colley, Linda (1996), Britons: Forging the Nation 1707 - 1837. London: Vintage.

Davies, Norman (2000), The Isles: A History. London, Basingstoke and Oxford: Papermac.

Evans, Eric (ed.) (2000), Illustrated Guide to British History. Bath: Parragon.

Fowler, Roger (1991), Language in the Necus: Discourse and Ideology in the Press. London: Routledge.

Frankova, Milada (1999), Divided Englishness: the North and South of the Mind in Looking into England Conference Report, www.britishcouncil.org.uk.

Giles, Judy and Tim Middleton (1999), Studying Culture: A Practical Introduction. Oxford: Blackwell Publishers Ltd.

Giles, Judy and Tim Middleson (eds) (1995), Writing Englishness 1900 - 1950. London and New York: Routledge.

${ }^{9}$ This vision is proposed by The Report (The Runnymede Trust 2000: x); Castells (1997) defines it as 'Project Identity'. 
Gray, Ann and Jim McGuigan (eds) (1993), Studying Culture: An Introductory Reader. London:

Edward Arnold.

Hall, Stuart and Paul Du Gay (eds) (1996), Questions of Cultural Identity. London: Sage.

Hall, Stuart (ed.) (1997), Representation Cultural representations and Signifying Practices. London:

Sage.

Hartley, John (1982), Understanding Nezus. London: Routledge.

Hosbawm, Eric and Terence Ranger (1997), The Invention of Tradition. Cambridge: Cambridge

Univeristy Press.

Johnston, Philip (2000), "Straw wants to rewrite our history," Daily Telegraph, 10 October.

Keith, Michael and Steve Pile (eds) (1993), Place and The Politics of Identity. London and New York: Routledge.

Leonard, Mark (1997), Brituin TM. London: Demos.

Leslie,Ann (2000), English Identity in www. popcultures.com, 19 November.

MacLachlan, Gale and Ian Reid (1994), Framing and Interpretation. Melbourne: Melbourne University Press.

Montgomery, Martin and Beth Edginton (1996), The Media. Britain: The British Council. Negrine, Ralph (1994), Politics and the mass Media in Brituin, $2^{\text {nd }}$ edn. London: Routledge. Paxman, Jeremy (1999), The English. Harmondsworth: Penguin Books.

Rattansi, Ali (2000), On Being and Not Being Brotun/Black British, Interventions, vol. 2 (1).

Storey, John (1997), An Introduction to Cultural Theory and Popular Culture, $2^{\text {nd }}$ edn. Hemel Hempstead: Prentice Hall/Harvester Wheatsheaf. 